GLOBAL DEVELOPMENT AND ENVIRONMENT INSTITUTE

Working PAPER No. 03-11

\title{
Clocks, Creation, and Clarity: Insights on Ethics and Economics from a Feminist Perspective
}

\author{
Julie A. Nelson
}

October 2003

Tufts University Medford MA 02155, USA

http://ase.tufts.edu/gdae 


\title{
Clocks, Creation and Clarity: Insights on Ethics and Economics from a Feminist Perspective
}

\author{
Julie A. Nelson
}

julie.nelson@tufts.edu

\begin{abstract}
This essay discusses the origins, biases, and effects on contemporary discussions of economics and ethics of the unexamined use of the metaphor "an economy is a machine." The neoliberal view that the self-regulated workings of free markets should be kept free of impediments is based on this metaphor. Many of the critiques of capitalist systems are, as well. The belief that economists simply uncover universal "laws of motion" of economies, however, is shown to be based on a variety of rationalist thinking that — while widely held-is inadequate for explaining lived human experience. Feminist scholarship in philosophy of science and economics has brought to light some of the biases that have supported the mechanistic worldview. By structuring thought and language in dualistic categories such that alternatives to a mechanistic worldview are labeled as "soft," the mechanistic view maintains some of its power by seeming "masculine" and "tough." Possible alternatives to the "an economy is a machine" metaphor are discussed in their relation to developments in philosophy, psychology, and the natural sciences. The essay argues that metaphors such as "an economy is a creative process" and "an economy is an organism" are both intellectually defensible as guides to scientific inquiry and provide a richer ground for moral imagination.
\end{abstract}

\footnotetext{
${ }^{1}$ This essay was presented at the meetings of the Societas Ethica in Sigtuna, Sweden, August 2003 on the theme of "Economics, Justice, and Welfare." I thank Carl-Henric Grenholm and the Society for the invitation to speak, Ann-Cathrin Jarl for inspiration and encouragement, and attendees of the conference for their very helpful comments. A shortened version of this essay will be submitted to a special issue of Ethical Theory and Moral Practice.
} 


\section{Introduction}

For an audience of mainstream economists, the first order of business when addressing the subject of "economics and ethics" is always to justify spending any time on the topic. What, after all, does ethics—a normative subject-have to do with economics? To most of my economist colleagues, economics is a positive science that seeks to understand the mechanisms underlying economic systems, primarily though application of ever-more-sophisticated mathematical models and econometric tests. Ethics, to them, seems like a soft, subjective, squishy subject, necessarily encompassing value judgments and ambiguity — not, in their perception, a "hard" field, with clear, objective, and defensible results, like their own. Most economists believe that economic science can proceed just fine without attention to ethics.

To the audience of ethicists from the fields of philosophy and religion to which this essay is addressed, however, I presumably do not need to justify ethics as an interesting subject. And since the theme of this volume is about economics and ethics, I do not need to justify the relevance of economic issues to ethical concerns.

What I find surprising, however, in much of the literature I've read on economics and ethics from the side of ethicists is the amount of agreement that they express with some of the very same - and highly questionable — assumptions that allow my economist colleagues to dismiss ethical concerns so easily. I find these areas of agreement in the works of politically conservative advocates of free markets and in the works of politically progressive critics, in the work of religious scholars and of secular scholars.

\section{The "Science" Trump Card}

The problem, as I see it, is that mainstream economists have generally successfully_and deceptively_-played the "science" trump card in dealing with philosophical and religious ethicists.

Many scholars implicitly assume that mainstream economists, though scientific study, have discovered what is really going on in market economies, and that others must bow to their expertise. Christian ethicist John Atherton, for example, defers in an article on "Where do Spirituality and Economics Meet?" to economists' knowledge of the "mechanisms and systems" that make up "the reality of the relatively autonomous world of economics" (1994, pp. 10,11). For Atherton, the recognition of this "relatively autonomous" realm justifies supporting serious consideration of Christian conservatism.

The same idea also appears in philosophy from the progressive left. For example, in the New Left Review political theorist Nancy Fraser writes about "relatively autonomous markets" that "follow a logic of their own" separated from culture and values (2000, p.11). Even religious scholars committed to a view of a living, breathing universe generally seem to come to a halt when they get to the economics boundary: Ken

\footnotetext{
${ }^{2}$ Nothing in the present paper should be construed as an argument against a much more modest point in favor of at least partial reliance on market systems: markets can have significant informational advantages over systems of central planning. The vast majority of observers of economies, even on the left, now grant that elements of market coordination can be helpful. Current debates are about achieving an appropriate mix of "free" market, regulated market, and non-market forms of organization.
} 
Jones in The New Social Face of Buddhism states, for example, that corporate polices are "determined by the 'logic of the market"' (2003, p.162).

All these scholars take as a truism that capitalist market economies function according to universal and amoral laws-whether the purpose of the writer is to argue for such systems or to seek to derail them. They accept the notion that market systems are mechanisms bound to the logic of competitive "market forces" and fueled by the energy of self-interest. They assume that contemporary economies function on a plane where the sorts of values-like responsibility and compassion - that we demand in other parts of our human life experience do not apply.

The science trump card works by way of a false analogy. The base of the analogy is the relation of religion to early discoveries in science-say, in particular, astronomy. Christian doctrine for centuries taught that the universe had three tiers-heaven for reward, earth for divine testing, and hell for punishment. But Copernicus and Galileo demonstrated, using direct observation combined with some mathematical calculations, that the earth was not the center of the universe. While religious authorities resisted this finding for a very long time, they eventually were forced to accept the scientific evidence. They had to admit that astronomical bodies worked according to a system that was apparently independent of moral rewards and punishments in spite of the contradiction this presented to traditional religious belief.

Now rerun the story, changing "religion" to "ethics" and "astronomy" to "economics." Direct observation and mathematical calculation demonstrate that market economies run thus-and-so, independent of how we might like or hope for them to run, and independent of our moral concerns, the story would go. Ethicists must therefore, like the religious leaders of old, bow to these scientific findings - or so the analogy implies.

The weak link in this argument is that while astronomy started with direct observations, the economic theories referred to start not with observation but with a highly biased set of assumptions. These assumptions about the subject matter of economics, about what it means to be human, and about methodology arguably do not accord well with observation and experience at all.

This paper describes these too-easily adopted assumptions, shows how they contain a high degree of arbitrariness and bias, and argues that conceptions of both ethics and economics can be made far richer and more adequate by loosening our attachment to the metaphorical image that "an economy is a machine."

\section{Metaphor and the Ontology of Mechanism}

"The essence of metaphor is understanding and experiencing one kind of thing in terms of another," as linguist George Lakoff and philosopher Mark Johnson said in their book, Metaphors We Live By (1980, p. 5). According to Lakoff and Johnson, and numerous other researchers in the areas of cognition, philosophy, rhetoric, and linguistics, metaphor is not merely a fancy addition to language, but is instead the fundamental way in which we understand our world and communicate our understanding from one person to another. Lakoff and Johnson give many examples of how the language we use reflects metaphorical elaborations of more abstract concepts on the foundation of basic physical experiences. Our perception of "up/down," for example, 
forms the basis for "good is up, bad is down," "reason is up, emotion is down," "control is up, subjection is down," and "high status is up, low status is down." Richer meanings can be found in more complex metaphors such as "argument is war" (reflected in language like "win," "lose", "defend," "attack"), "argument is a journey" (e.g. "step by step," "arrive at conclusions") or "argument is a building" (e.g. "groundwork," "framework," "construct," "buttress," "fall apart").

These metaphors affect our understanding and our action: for example, if we perceive ourselves as engaged in an argument, how we interpret what we hear and how we respond depends in good part on which metaphor we use. Metaphorical understanding is also culturally variable. For example, as Lakoff and Johnson suggest, there could exist another culture that uses the metaphor "argument is dance" and so uses language of esthetics, style and synchronization.

The basic metaphor underlying the understanding of what an economy is, in the neoclassical view, is that "the economy is a machine." It runs by "mechanisms." It is driven by "forces." This is perhaps seems so obvious to us, so naturally true, that it is worth sketching the way in which economics grew out of a particular historical and cultural milieu in order to recognize that it is a metaphor.

As is well known, beginning in the sixteenth century in Europe the predominant conception of the relationship between humans and nature began to undergo a radical conversion. In medieval times, humans had been seen as embedded in a living cosmos. From Galileo's early work in mechanics, through Descartes' elaborations and finally Isaac Newton's culminating work, the idea of the world as a sort of giant clockwork mechanism, whose activity is reducible to components and forces describable in terms of laws and mathematics, radically changed the way people thought about the material world.

René Descartes split the world into a "res cogitans" and a "res extensa." Knowledge was seen as a part of the cogito, radically detached from passive matter. Descartes, of course, believed that the only knowledge that can count as true is that explained by theorem and proof, a la mathematical geometry. Sensory experience came to be regarded as not to be trusted. As Enlightenment thought further developed, people were encouraged to think of men as potentially detached, objective observers and controllers of nature. Reason, seen as a force separate from bodily experience, was to be the path to clarity, certainty, and security. The mind-pictured as "over here" in the realm of res cogitans-would know and gain control over the world-pictured as "over there" in the realm of res extensa-by mentally figuring out the rules by which the clockwork runs. The whole world was seen as, at base, a system of equations which the mind could discover.

Not surprisingly, when Adam Smith described economic and political life in the eighteenth century, he used the metaphors of his day. "Power and riches" he wrote, are "enormous and operose machines" (1759 [1976], p. 182). The "wheels of the political machine," he continued, can be made to move in harmony when one attends to "the connexions and dependencies of its several parts" (1759 [1976], pp.185,186). Smith is most noted, of course, for arguing (at least in one instance, in The Wealth of Nations-but this is what has become most famous) that individuals' pursuit of their own self-interest 
is made, by the amazing mechanism of a self-regulating market system, into service to the good of others: "It is not from the benevolence of the butcher, the brewer, or the baker, that we expect our dinner, but from their regard to their own interest. We address ourselves, not to their humanity but to their self-love, and never talk to them of our necessities but of their advantages." Since Smith, self-interest has been assumed to be the energy source driving the gears of economic production.

These Enlightenment thinkers, of course, generally did not see (or at least, given the power of the Church of the day, express) any conflict or even break of subject matter between science and the sorts of questions of value and purpose expressed in religion and philosophy. Smith, the author of The Wealth of Nations, was also the author of The Theory of Moral Sentiments. To most Enlightenment thinkers the notion of nature as a clock was inseparable from the notion of God the Clockmaker. The world could be both mechanical and full of purpose and value, because it had purpose and value in God's eyes.

Later scientists and philosophers, however, noticed that, in fact, the study of the clockwork moved along just fine without any notion of purpose, value, or ethics. The notion of a Clockmaker became increasingly irrelevant to scientific work. Secularism and a mechanical reductionism increasing took the place of rhapsodizing about divine intention in the practice of scholarly science and economics. Darwinian evolutionary theory accelerated this process, by positing a mechanism other than once-and-for-all divine design by which the living parts of the clockwork might have been elaborated.

Jumping forward a few centuries, we see these rationalistic and mechanistic images of humanity and nature still informing many projects in the natural and social sciences. Some physical scientists, social scientists, and philosophers dream of consilience between the natural sciences and humanities - they believe that we are approaching a point in which all of existence, including all of human consciousness and ethics-will be understood in terms of a few fundamental natural laws (e.g., Wilson, 1998).

Contemporary economics is dominated by the neoclassical paradigm, which is very much based on a Newtonian idea of a clockwork world. The focus is directed at the issue of choice behavior in the face of a fundamental scarcity of resources. Under certain additional technical assumptions, choice behavior can be elegantly portrayed as an optimization problem solvable by standard calculus - very much like the Newtonian physics from which the model's early developers (such as W. Stanley Jevons and Léon Walras, in the late 1800s) explicitly derived their inspiration.

In order to make mathematical modeling tractable, however, economists have had to adopt a number of assumptions, such as that economic agents are autonomous, rational, and self-interested and that agents solve very simple maximization problemsconsumers maximize utility, and firms maximize profit. In the core model, it is also assumed that market coordination is the only, and only necessary, form of coordination among individual agents.

Regarding questions of value, economists can shirk all concern with ethics by, first, assuming that the formation of consumer preferences is a subject outside of the scope of economics and that consumer sovereignty must be respected, and second, by 
claiming that interpersonal comparisons of well-being are not scientifically justifiable. That is, it is assumed that whatever people want is best and that economists can say nothing about distribution.

Efficiency, then, becomes the only measure of value about which economists have anything to say. One of the big results of neoclassical economics is expressed in what is called the First Fundamental Theorem of Welfare Economics: A perfectly competitive free market economy will be efficient. By "efficient," the economist means "Pareto efficient." A situation is Pareto efficient if there is no change that could make someone better off without making someone else worse off. By "perfectly competitive," the neoclassical economist means that there are so many buyers and sellers in every market that none have any power to influence the price they pay or receive.

Perfectly competitive firms, while acting out of self-interest, are not able to run inefficiently—say, with costs that are above their absolute minimum—-because their more efficient competitors would run them out of business. This culling of any high-cost firms is what is often referred to as "the logic of the market."

As a corollary to the First Fundamental Theorem, most textbook expositions of neoclassical theory then go on to show how government "interference" in a free competitive economy - for example, through taxes, trade barriers, or social welfare transfers to the poor-reduces economic efficiency. They may go on to argue, somewhat more loosely, that such interference also reduces private innovation and economic growth. In this way, neoclassical economic theory provides an intellectual—and mathematically elegant-justification for neoliberal, minimal-government, free-trade and free-market policies, such as those recently propounded in the U.S. and Europe by conservative leaders, and for developing and transitional economies by the International Monetary Fund and the World Bank.

The mathematics of the neoclassical model are taken as representations of the unseen forces at work in the economic machine. The mathematics also serves, conveniently, as a protection for the priesthood of economists. Scholars in the humanities who might venture a criticism or want to examine an assumption can often be impressed or intimidated, we economists have discovered, by references to subgameperfect equilibria or heteroskedasticity.

Regarding ethics, recently some attention has been given within economics to ethics in the form of social norms (such as of reciprocity and revenge). However, the dominant approach has been to portray these reductionistically as evolved behaviors in service of the long-run self interest of the rational, self-interested, autonomous individual agent. If, in some cases, certain social norms (such as for soldiers to sacrifice themselves during war) cannot be explained as helpful coordination mechanisms a self-interested human individual, then believers in the self-interest-and-optimization approach can fall

\footnotetext{
${ }^{3}$ The core model is not the whole of mainstream economics, since the profession has expanded somewhat to include investigation of what happens when various assumptions of the core neoclassical model are loosened-generally one at a time. Attention to non-competitive-market interactions using game theory, to transactions costs and behavioral factors, and more serious attention to market and government institutions characterize some approaches that are nevertheless considered fairly mainstream. Yet in each case, the core assumptions other than the one or two being weakened at the moment are usually assiduously maintained.
} 
back on analysis at the level of self-interested genes (see, e.g., Ben-Ner and Putterman 1998).

In fact, in mainstream economics the agents are (perhaps surprisingly) rather passive and lacking in agency. Once you know the consumer's utility function, everything else about the consumer can disappear. The consumer's purchase behavior rolls out automatically. A firms' profit maximization problem likewise reduces to a simple bowing to competitive market forces. At their narrowest, neoclassical economists demand that all economic phenomena be explained entirely in terms of "economic fundamentals"- preferences and technology combined with market forces-leaving no space for moral agency or regard for social or political movements. The system is locked up. Real decisions of any kind-ethical or not-hardly come up at all. A gear in a machine, after all, only does what the gear next to it pushes it to do.

The ideas that there could be any fundamental sense of sociality and interrelatedness in human nature, or fundamental drive other than self-interest, or meaningful decisions to make, are not allowed to enter. Ethics, purpose, and value, in this view, disappear except perhaps as an interesting epiphenomenon of physics and evolution-similar to the current extreme reductionist view of religious feelings, that sees them as no more than neural activities in the temporal lobe of the brain.

\section{Economics and Ethics Within the Clockwork Image}

How, then, can economics and ethics be reconciled? Reading in this area, I have seen a wide variety of approaches-whose one common theme is that they accept without question the notion of economies as machines powered by self interest.

One approach is to continue to carry forth the God-the-Clockmaker image, explaining that yes, the world is a machine, but it's God's machine and hence moral. In regard to economics, we see this in the assertions of scholars like Michael Novak (1981[1995]), for whom the free market is not only praiseworthy, it is a sign of God's presence. Moral behavior in regard to economics, in this view, consists in keeping Adam Smith's "enormous and operose" machine well-oiled and free of impediments. One must, of course, put enormous belief in the free market model, and enormous ethical weight on the value of individual freedom over economic justice, to accept this view in its pure form.

At the other extreme, some of the more mechanistic parts of Karl Marx' writings strongly influenced radical struggles for justice for many decades. Capitalism is powered by a drive for accumulation, it was said. One of Marx' stories-illustrated with equations - posited that contradictions within capitalism (most importantly, a falling rate of profit) would inevitably lead to its replacement by socialism. This was a comforting thought, for those who sought greater economic equality. Greed and class conflict would, presumably, automatically extinguish themselves. Scientific Marxism seemed to offer a "hard," theoretically justified road to achievement of an ethically desirable goal. To all but the most diehard scientistic Marxists, however, the accuracy of this model now appears highly questionable.

More often, in contemporary writings, religious and secular critics of contemporary capitalism fall back on dualistic thinking. They take as true the idea that 
businesses and market systems are machines. Generally, like Smith, these scholars see self-interest as the energy source of a market economy. However, contrary to Smith and in line with more traditional religious and moral teachings, they note that self-interest often works against the social good. These scholars note that some people hoard wealth while others receive too little for their work to survive, and that ever-increasing consumerism may be bringing us to the brink of ecological collapse. As a result, contemporary markets systems are perceived of as in need of something - at least some adjustment or balance, or perhaps going farther, replacement - in order to meet ethical concerns.

There are several variants of dualistics approaches.

One is to set up a pessimistic dualism with irrevocably mechanical, self-interestdriven markets on the one side, and a concern for purpose, value, morality and a higher good on the other. Max Weber's contrast between the "iron cage" of irresistible technical and economic forces and the human search for meaning set the ground rules for engagement in sociology. In theology and philosophy, Reinhold Niebuhr's claim that ethics at the level of the individual do not apply at the social level strongly influenced the thinking of his time and of many to this day. Starting from a reason vs. nature dualism, Niebuhr (1932 [2001]) argued that religion and reason are not enough to control the "natural impulses by which society achieves its cohesion...."-where "natural impulse" meant_-for Niebuhr just as for Adam Smith—-self-interest. While this view allows for discussion of economics and ethics, the prognosis for economic justice is grim. Ethics and economics play an agonistic game, with self-interest assumed to hold the stronger hand. Perhaps apocalypse is on the way.

Another sort of dualism is created when one thinks of our current economic systems as irretrievably "fallen," and then looks entirely to "structural" or "systemic" changes for ethical relief. Writer Ken Jones (mentioned earlier) and feminist theologian Carol Robb (1995), for example, are among the many writers who argue that ethical demands require a thorough-going transformation of contemporary economic systems. The analysis tends to combine elements of mechanical thinking from neoclassical economics with somewhat more moralistic thinking with a Marxist flavor.

That is, from neoclassical economics, they take the assumption that firms are units that maximize profits, and who are driven by competitive market forces to use the lowest cost production techniques. However they notice that, for example, the drive to lower costs can result in workers being paid below-subsistence wages. ${ }^{-1}$ These critics, taking dire poverty as an ethical concern, conclude that market systems are inherently, by their own "logic," damaging of human dignity.

However, to this "logic of markets" story, they also add discussions of the power of corporations and/or of "global elites"- the directors of multinational corporations and international financial institutions. There is a bit of a logical contradiction going on in this mixing of models, which is worth taking a slight side-track to point out. Within neoclassical economic theory, the idea that a free-market system creates the greatest

\footnotetext{
${ }^{4}$ Within the Neoclassical model, such poverty is not a major focus, since people are assumed to be autonomous, choosing agents. Consideration of consumption below the survival level would create an awkward "discontinuity" that would make the mathematical modeling less elegant.
} 
efficiency applies to a perfectly competitive economy. When corporations have market and political power - as all but the most diehard neoclassical economists must admit that multinationals have, at least in some markets and countries - then neoclassical theory says that market forces are stymied - they will not do their job of forcing efficient outcomes. As an empirical point, most large corporations do seem to run with some "slack," which gives their directors more flexibility regarding their chosen policies-for good or ill.

So once we recognize that market power gives companies some discretion, we are really bounced out of the perfect-competition-and-efficiency model, and into one that includes the possibility of some real choices. The critics, however, then immediately assume-based perhaps partly on the assumption that economic actors are fundamentally always self-interested, perhaps partly on an image of Marxian class struggle, and backed up by historical incidents of morally abhorrent corporate behavior-that such power will necessarily be used for "ill." Power-hungry capitalists and greedy corporate elites will, it is assumed, use any discretion given to them by market power for further selfaggrandizement.

Since, whether driven by "market logic" or greedy elites, capitalist economies spawn ever increasing assaults on human dignity, such critics suggest relatively drastic reforms. Robb, for example, accepts the notion of the machine-like functioning of economies but wants to change who is at its "controls." State intervention in line with the common good is prescribed, to replace selfish control by the corporate elites. Others, along a more utopian line, advocate completely replacing systems of corporations and markets with forms of organization that are more cooperative, more local, more democratic, and more directly in line with love-thy-neighbor ethical and religious teachings. If contemporary systems are "fallen" and immoral, then, it is supposed, one must look to a thoroughgoing systemic or structural transformation for the advent of economic justice. E.F. Schumacher's (1973) Small is Beautiful would be an example of this kind of view. Herman Daly and John Cobb (1989) also look largely to issues of scale for relief. We might group these together in a class called the "systemic critique."

Rather than pit ethics against capitalist economies in general, another variant creates a dualism within existing contemporary economies. Part of the economy, it is suggested, can more or less safely be given over to "market values." Presumably a-moral, mechanical markets can be allowed to operate in some realms where efficiency is highly valued-say, in provision of consumer goods. But some realms of economic provisioning should be walled off from contamination from instrumental values, and held to higher standards. Health care, education, and child care, for example, are among those spheres that are often thought of as needing protection from "commodification." The work of philosophers Elizabeth Anderson (1993) and Michael Walzer (1983) goes some way down this road, and this view is prevalent among a number of feminist theorists and social scientists. We might call these, as a group, the "separate spheres" critique.

\footnotetext{
${ }^{5}$ In response to the presentation of this paper at the Societas Ethica conference in 2003, Anderson acknowledged that in her earlier work she had focused too much on self-interest when dealing with market exchange, but said she had broadened her more recent research into issues such as the roles of trust and cooperation within market activity. For a review of such a dualistic view in the writings of some feminist ethicists and other theorists see Nelson and England (2002).
} 
In all of these views, the notion that markets fundamentally operate independently of our ethical concerns is taken for granted. I find this unsatisfactory.

My critique of the "systemic critique" and "separate spheres" scholars, it should be made clear, is not with their argument that values beyond self-interest and profit maximization should play an important role in economic life. It is that "systemic critique" scholars too easily exclude the present economy, and "separate spheres" scholars too easily exclude the unprotected sphere of the economy, from ethical thinking. Both views assume that "the economy," unmodified, is inevitably permeated by-driven by - the very narrow values posited by the neoclassical economic tradition. There is little room in these arguments for the notion that people and organizations might be agents with moral responsibilities right now and right here-within contemporary economies.

They also implicitly — and somewhat naively in my view - tend to assume that self-interest is limited to the market sphere. They often seem to assume that if an organization is small, or incorporated as a non-profit, or governmental, then non-selfinterested motivations can be trusted to take over. Evidence of self-interest and violence within very small-scale organizations run according to values other than profit - such as families - should give us pause. Likewise a blind trust in the state (like a blind fear of the state) seems unwarranted. Yet some such dualism between the mechanical and the moral is endemic to discussions that take for granted that market economies are machines, and moral life must be lived elsewhere.

But - and here is where I believe the chance for a real branching past current limitations on thinking about ethics and economics opens up-do we have to believe that the economy is a machine? Do we have to believe that self-interest is its sole "natural" energy source? The image is so familiar to us, and so tied up for centuries with our notions of science that it may be hard to think about what economic knowledge would mean outside of that image.

\section{A Feminist Critique of Mechanism}

Feminist scholars such as Evelyn Fox Keller (1985) and Sandra Harding (1986), beginning in the 1980's, began to point out the gendered nature of the mechanistic world view that arose during the scientific revolution. Those things taken to distinguish "man" from "nature" during the scientific revolution were also taken to distinguish "man" from "woman." Science was identified with masculinity, detachment, rationality, and domination of nature. Nature was personified as feminine-and correspondingly seen as passive and submissive. Older views of nature as alive with interconnections and meaning, powerful, chaotic, and beyond mechanical control were dismissed as superstitious - as leading to belief in witchcraft, not science. The gender associations in the rise of science were sometimes explicit. Henry Oldenburg, an early Secretary of the British Royal Society, stated, for example, that the intent of the Society was to "raise a masculine Philosophy ... whereby the Mind of Man my be ennobled with the knowledge of Solid Truths" (Keller, 1985, p. 52).

Gender, in much of the feminist literature, is distinguished from sex: sex is used to refer to biological differences, while gender refers to social understandings constructed on the base of perceived physical sexual dimorphism. So the argument here is not that 
women or nature "are" passive, in some essential way, but that both women and nature have been culturally and cognitively associated with characteristics that were deliberately cast aside in constructing the notion of a "masculine" science. The counterpoint to the rational, detached "man" of the Enlightenment age is, as historian of science Elizabeth Fee put it, “... woman [who] provides his connection with nature; she is the mediating force between man and nature, a reminder of his childhood, a reminder of the body, and a reminder of sexuality, passion, and human connectedness. She is the repository of emotional life and of all the nonrational elements of human experience." (1983, p. 12). Men and women both start out as children, have bodies, and are sexual and emotional beings - it is just that these characteristics have been purged from the notion of the Enlightenment "rational individual (man)" and projected onto its shadow, the image of the connected and natural woman.

Following on this feminist scholarship of the 1980's, feminist economists in the 1990's began to point out how gender biases have played out in contemporary economics (Ferber and Nelson, 1993; Kuiper et al., 1995; Nelson, 1996). The definition of economics according to markets, individual agents, efficiency and "positive" questions excludes families, society and institutions, equity, and normative concerns. In seeking to be rigorous, precise, objective, mathematical and abstract, the profession pushes off to its margins anything that seems intuitive, vague, subjective, verbal, or overly concrete. The assumption that agents are self-interested, autonomous, rational choice makers puts into the shadow any social, other-regarding, interdependent, emotional, or habitual characteristics that may be important for explaining economic behavior. The cultural connotation for what is favored is "hard" and "masculine," while for the the disfavored the connotation is "soft" and "feminine."

Take a few examples of the assumptions of the core neoclassical model, and notice what they leave out.

For example, the assumption that goods are fundamentally scarce is rather a different view of reality than one might expect to see arise in contemporary wealthy economies. Another view might emphasize the abundance we have around us. But one would search high and low in vain in economics to find the sort of basic attitude of gratitude for abundance expressed in the simplest religious dinner grace or harvest hymn. The neglect of enjoyment of economic life does, indeed, go back to Smith and have gendered overtones. Echoing Descartes' trust in reason and distrust of experience, Smith made a distinction between our experience of economic life and satisfaction and our reason which allows us to understand and admire the grand machine of economic industry. Smith wrote that we tend to ignore the "real satisfaction" that abundance brings in favor of focusing on "the regular and harmonious movement of the system, the machine or oeconomy" (1759 [1976], pp. 182-3). "And it is well that" we do so, Smith argued, since this fascination with system is what keeps industry humming. Smith went on to commend the "active, resolute, and sober" character who would ignore the satisfactions of abundance in order to serve the economic machine, and derided the "slothful, effeminate, and voluptuous" character who would be less inclined partake in the spirit of industry (1759 [1976], p. 187, emphasis added). The notion that sensual

\footnotetext{
${ }^{6}$ Likewise, contemporary American religious thinker Peter Berger contrasts the traditional economic ethics of "hard work, postponing enjoyments, discipline, sobriety" with a new economic culture that arose in the
} 
enjoyment is feminine and to be repressed is reflected at the core of economic thinking. Descriptions of consumer behavior in contemporary economics, for example, do not emphasize notions of desire and enjoyment. Instead, consumers are said to try to get to a higher curve representing "indifference." Ethicists could use this: What a difference it could make to a consumer culture if people were actually encouraged to slow down and appreciate what they have!

Notice, also, that when economic agents are assumed to be autonomous and selfinterested, then what gets pushed into the background are human connections and human concern for other people and the larger good. Social embeddedness is denied. Children, sick people, and frail elderly people are not recognized in the neoclassical model-they do not fit the assumption that individual agents are autonomous. The people who out of concern nurture and care for them, often for little or no reward, are also not recognized by the model-they do not conform to the assumption of self-interest. Traditionally, these have been largely women.

However, when open-minded researchers actually look at the values people bring to economic life, they overwhelmingly find more than self-interest that the mechanical model assumes. Within economics, experimental economists have noticed that subjects in various economic simulations regularly tend to cooperate "too much" relative to what is predicted by economic theory (Camerer and Thaler, 1995). Researchers on organizational behavior and business ethics have found dimensions of loyalty, a search for purpose and meaning, identification with work and with community-even within corporations making widgets (Collins and Porras, 1994; Paine, 2002; Solomon, 1997). Yet emotions, connections, "soft skills"-all these have been made to seem less "rigorous" than the neoclassical assumptions.

One may very well argue that non-self-interested motivations are too weak in economic dealings to lead to meaningful ethical behavior within contemporary economic systems. I myself am not overly optimistic on this score. But denying that they exist can, by undercutting them, very well help turn the emphasis on economic self-interest into a self-fulfilling prophecy. People who are told that economies run on greed are likely to conform themselves to what they believe to be the norm. Researchers have found, for example, that taking college courses in neoclassical economics leads to a measurable decrease in cooperative behavior (Frank et al., 1993).

The emphasis on rationality in the narrow mainstream economic model is also worthy of suspicion. While factors such as emotion and intuition are culturally coded as "feminine" as opposed to "masculine" logic, recent developments in psychology—most notably by Nobel Laureate psychologist Daniel Kahneman and Amos Tversky (1994, 2000)_-have shown that real-life human decision making has many emotional, habitual, and otherwise not-perfectly-logical elements.

We could go on. Assuming that "firms maximize profits" means that dealing with the different interests and the variety of ethical understandings and types of knowledge that might be held by managers, workers, suppliers, customers, and shareholders can be ignored. If the Asian financial crisis of 1995 was precipitated by bad internal and 
external governance at Barings Bank, or the stock market plunge of 2002 was at least at part brought on by a crisis of trust after the news of the scandals at Enron, WorldCom, etc.-well, these incidents are, apparently, not quite core "economic" issues, by the neoclassical definition.

Assuming that market coordination is the only necessary form of coordination assumes away economic phenomena that occur at levels above and beyond that of the individual market transaction, like public goods, externalities, and the wielding of power.

Assuming that preferences are given means that the model takes no account of how our social environment or our own actions may rebound on what we want-or even effect who we believe ourselves to be. In the core model, for example, paid work enters only as something which brings in income while taking away from leisure. There is no account for how we might find meaning, purpose, and enjoyment through our reaching out into the world in productive activity. Unpaid work done by women is usually not recognized at all.

And, of course, the assumption of no interpersonal comparisons eliminates all considerations of distribution and poverty. The many assumptions needed to make the neoclassical, mechanical, model tractable, then, are all quite open to question.

The feminist analysis suggests one reason why mechanical metaphors in economics have had staying power. Any challenge to the basic metaphor or the assumptions of the core model can be dismissed by being called less "rigorous," less "hard"- that is, more feminine, soft, relativistic, subjective, romantic, superstitious, voluptuous, etc. Making room for any of the factors on the excluded side of the gendered division of what is "economics" and what is "not economics" raises the risk that the image of the male scientist who is control of a passive and thoroughly knowable nature might have to be questioned. This may be a scary thought. It seems much safer to stay with an image of science that emphasizes a dry set of methodological stipulations or the inexorable discovery of cool natural laws. Feminist analysis suggests that our cultural attachment to certain notions of science and economics may itself have social, psychological, historical and gendered roots.

Rather than accept the definition of economics as it is, Enlightenment roots and all, the feminist critique encourages us to look at its one-sidedness as an issue of bias rather than a sign of "rigor." The neoclassical model elegantly describes a mechanical world that it has imagined for itself; feminist critique encourages us to question the relevance of such theories for the world in which we actually live and act.

\section{Changing Metaphors}

What if we thought in terms of "an economy is a creative process"? Or what if we thought in terms of "an economy is an organism"? What if we thought of economies

\footnotetext{
${ }^{7}$ For more on the theory of the firm, see Nelson (2003a).

${ }^{8}$ Because of various histories of association, metaphors may carry various meanings. To some readers from eastern Europe, for example, may associate the term "organism" with a Marxist idea that only the larger economy - and not individual persons-is important. I thank discussants at the Societas Ethica conference for pointing this out. This is not the meaning intended here. The point of this paper is not to argue for one
} 
as part of an ongoing process of creation, that involves us as full humans-bodies, ethics, and all? What if we thought of science in terms of sustained, careful, open and purposive inquiry?

Such thinking would not rule out sometimes using the rhetoric reminiscent of nonliving machinery or structures. Talk of forces and mechanisms can sometimes be useful, since sometimes such talk highlights and gives insight to a specific item of concern. But it would demand that the metaphor of "an economy is a machine" be recognized as a metaphor as it is being used, not confused with universal truth. That the mechanical metaphor tends to hide other aspects of reality should not be forgotten. For example, within the metaphor "the economy is an organism" we can still have the (partial) understanding, "the economy is a structure." Consider: What makes a human being (organism) able to stand? In part, it is the structure of the skeleton: a weightbearing system, analogous to a non-living bridge or building. Without a properly aligned skeleton, standing is impossible. But from another angle, one could name many other things - breath, circulation of blood, correct workings of the inner ear, willpower-that make a human able to stand. Take away any one of these, and standing is equally impossible, even if the skeletal structure is present. Likewise, an economy has an institutional structure of businesses, families, communities, governments, markets, regulations, standards, etc., and also is sustained, continually created, and potentially transformed by beliefs, norms, relationships, aspirations, concerns, satisfactions, and ethical reflections.

What the expanded metaphors could do is integrate us back into our economic world, integrate our purposes and values with the lives we actually live, locate us bodily and mentally at the point in time where our decisions-which are usually at the same time both economic and ethical — enter the flow of the world's creation and, in a small way, change the future. Perhaps instead of thinking of the economy as a machine that must always be run to produce more, we might pause and see if we enjoy what we have, and whether what our economies produce adds to the flourishing of human life and to the flourishing of all of creation. Instead of either/or dualisms of reason $v s$. nature, or the divine vs. nature, or the ethical vs. the economic, a view of the world as constituted in purposive process allows both/and thinking. The economy is in many places loose enough, alive enough, evolving enough to allow us choices-real choices - to act for good or ill. Contrary to the conservative defenders of free market ideology, the economy is not a closed system. Contrary to the critics of global capitalism, the economy is not a closed system. Thinking of the economy as a living, creative process, we can recover the idea that choosing and acting for good may be possible.

\section{Resources for a Non-Mechanistic View}

While this paper is not the place to develop the expanded metaphors of organism and creative process at length, I can point to many developments in thinking about science, economics, and philosophy, that might inspire and inform a movement out of economy-as-machine thinking.

particular alternative metaphor for economics, but to argue that useful alternatives exist in which human moral agency can be included. 
One way to restate my argument, for example, would be to say that we have tended to take the economy as an "it" rather than as a "Thou." In Martin Buber's famous philosophical piece on identity and relation, I and Thou, he wrote about the fallacies of a non-relational worldview in which we imagine either "the world...embedded in the $I$, and that there is really no world at all," or "the I...embedded in the world, and there is really no $I$ at all" (1958, pp. 71-72). The rather un-agenic agent of neoclassical economic theory is an prime example of both sides of this coin. In concentrating attention on the choice processes of logic-driven autonomous individuals, the reality of bodily and social experience is made to disappear-the world is absorbed into the mental $I$. On the other hand, the idea that firms are driven by competitive market forces, or that a consumer is no more than a pre-existing utility function, makes the $I$ disappear, so only a world of unconscious clock-workings and equations remains. What is needed is a more relational image of how we develop as humans and act in our social and natural worlds.

Besides Buber's work, resources for more process-oriented and relational thought in philosophy can also be found in the work of Alfred North Whitehead and in the school of American Pragmatism, expounded by scholars such as William James and John Dewey. Work on ethics that does not fall back on absolutist notions of "natural law" can be found writings by Mark Johnson (1993) on the use of metaphor in moral imagination, and Martha Nussbaum (1995) on the relation of moral thinking to literature. Some feminist work on economic ethics and religion, such as by Sallie McFague (2001), also work beyond "natural law" theories towards understandings that include human creativity and responsibility. 10

Within economics, a less mechanical view was developed by the American Institutionalist School in the early decades of the 1900's. While by the late 1930s it was overtaken by the rise of logical positivism, it had earlier been a force to be reckoned with. It was founded by thinkers such as John R. Commons and Thorstein Veblen who saw economies as evolving process, and the role of economists as addressing new problems related to human and social well-being as they arose (Nelson 2003b). Societies such as the European Association for Evolutionary Political Economy and the (American) Association for Evolutionary Economics currently carry on some of this work. In replacing the mechanical metaphor of the neoclassical model with one that is more process-oriented the institutionalist school was in fact also joined by the school of Austrian economics, although that school, led by thinkers such as Friedrich Hayek, was considerably more optimistic concerning self-regulation of markets.

Perhaps most interestingly, notions of science itself have undergone considerable flowering since the Enlightenment. While neoclassical economics has stayed with a notion of science based on Newtonian physics, the actual natural sciences have (except for a continuing reductionist faction) moved on. In twentieth century physics, the development of quantum theory, the theory of relativity, and most recently the study of chaos and complexity reveals that the universe has non-mechanical, unpredictable, nonlinear, seemingly incommensurable, surprising and even "spooky" behaviors. While equilibrium, observability, predictability, control, simple determinism and continua

${ }^{9}$ For more detail, see Nelson (2003b).

${ }^{10}$ Beverly W. Harrison's (1985) use of the non-mechanical aspects of Marx' social theory is also interesting. See also discussions in Ann-Cathrin Jarl (2003) and Nelson (2003c). 
characterized the seventeenth-century scientific thought imported into economics, contemporary physics finds these to be only characteristic of special cases. More generally, disequilibrium, effects of the observer on the observed, impossibility of prediction and control, jumpy or chaotic processes, emergence and systems that are more than just the sum of their parts demand non-mechanistic and non-reductionist approaches.

Quite turning the idea that social sciences should emulate the "hard sciences" on its head, for example, physicists Nigel Goldenfeld and Leo P. Kadanoff write in their introduction to a section of Science entitled "Beyond Reductionism,"

Up to now, physicists looked for fundamental laws true for all times and all places. But each complex system is different; apparently there are not general laws for complexity. Instead, one must reach for 'lessons' that might, with insight and understanding, be learned in one system and applied to another. Maybe physics studies will become more like human experience. (1999, p. 89)

Meanwhile the contemporary theoretical physics of Ilya Prigogine (1997) combines the notion of natural "laws" (which are now only about probabilities) with the idea that timeirreversible "events" lend "an element of radical novelty to the description of nature" Like Alfred North Whitehead, Prigogine does not see human creativity as opposed to (or as an illusion in the light of) natural regularities. Rather, his project leads towards "a science that views us and our creativity as part of a fundamental trend present at all levels of nature" and which is integrally linked to "the building of tomorrow's society" (1997, pp. 7, 185).

Some of the most interesting recent developments, to my mind, have been those in cognitive psychology. At the time of the Enlightenment, the big question of concern seemed to be "What makes us different from (other) animals?" The answer given was "reason," and reason was imagined to give humans control over (presumably) mechanical nature. Recently, however, with centuries of development of machinery leading to the advent of Artificial Intelligence and the prospect that computers might develop "thinking," a new and in some sense diametrically opposed question has cropped up: "What makes us different from machines?" The answer given by many researchers is "bodies"- specifically human bodies and soft human brains, evolved to meet certain kinds of challenges in creative and constitutive interaction with certain kinds of environments. Studies of bodily experience, consciousness, phenomenology, subjectivity, and the role of the emotion in reasoning have recently been revived in status by cognitive scientists such as Gerald Edelman (2000), Antonio Damasio (1994), and Andy Clark (1997).

The mechanical metaphor begins to look more and more old fashioned, as well as damaging.

\section{Conclusion}

To those who have not investigated the source and limitations of the clockwork metaphor of economic functioning, suggesting that it be replaced by a more "organic" or "creative" view sounds simply soft-headed. "Sure, you can fit more ethical concerns in by taking economics to be a humanistic subject," thinks the listener, "but that is not 
rigorous, not scientific." Referring to an "organic" conception is more likely to raise in a listener images of granola and New Age music, than of serious investigation into realities, economic and otherwise.

If my arguments cause you at least to pause and have a second thought before dismissing ideas such as that economies may be vital, or that our ethical selves are part and parcel of our economic selves, or that being "soft" in some senses might be OK, then it has served its purpose. If it helps to bring ethical discussion more fully into economic discussions, with fewer excuses and fewer references to stale theories of social science inadequate for dealing with problems of poverty, discrimination and the ecological consequences of our economic behavior-this is even better.

Julie A. Nelson is a Senior Research Associate at the Global Development and Environment institute at Tufts University, USA, and Sowell Visiting Professor of Economics at Bates College, USA.

\section{REFERENCES}

Anderson, Elizabeth, Value in Ethics and Economics. Cambridge, Mass.: Harvard University Press, 1993.

Atherton, John, "Where do Spirituality and Economics Meet?" Journal of the Association of Christian Economists 17 (1994): 1-13.

Ben-Ner, Avner and Louis Putterman, "Values and Institutions in Economic Analysis," in Economics, Values, and Organization, ed. Avner Ben-Ner and Louis Putterman, Cambridge and NY: Cambridge Univ. Press., 1998, 3-69.

Berger, Peter, "Social Ethics in a Post-Socialist World" First Things 30 (1993), 9-14, reprinted in On Moral Business: Classical and Contemporary Resources for

Ethics in Economic Life, ed. Max L. Stackhouse, Dennis P. McCann, and Shirley

J. Roels, with Preston Williams. Grand Rapids: Eerdmans (1995).

Buber, Martin. I and Thou. New York: Scribner's, 1958.

Camerer, Colin F. and Richard H. Thaler, "Anomalies: Ultimatums, Dictators and Manners," Journal of Economic Perspectives, 9:2 (1995): 209-219.

Clark, Andy, Being There: Putting Brain, Body and World Together Again. Cambridge: MIT Press, 1997.

Collins, James C. and Jerry I. Porras, Built to Last: Successful Habits of Visionary Companies. New York: HarperBusiness, 1994.

Daly, Herman E. and John B. Cobb. For the Common Good: Redirecting the Economy Toward Community, the Environment, and a Sustainable Future. Boston: Beacon Press, 1989.

Damasio, Antonio R., Descartes' Error: Emotion, Reason and the Human Brain. NY: G. P. Putnam's Sons, 1994.

Edelman, Gerald M. and Giulio Tonomi, A Universe of Consciousness: How Matter Becomes Imagination. New York: Basic Books, 2000.

Fee, Elizabeth, "Women's Nature and Scientific Objectivity," in Women's Nature: Rationalizations of Inequality, ed. Marian Lowe and Ruth Hubbard. New York: Pergamon Press, 1983, 12. 
Ferber, Marianne A. and Julie A. Nelson, eds., Beyond Economic Man: Feminist Theory and Economics. Chicago: University of Chicago Press, 1993.

Frank, Robert H., Thomas Gilovich and Dennis T. Regan, "Does Studying Economics Inhibit Cooperation?" Journal of Economic Perspectives 7(2)(1993): 159-171.

Fraser , Nancy, “Rethinking Recognition,” New Left Review 3 (2000):107-120.

Goldenfeld, Nigel and Leo P. Kadanoff, "Simple Lessons from Complexity" Science 284 (April 2, 1999), pp. 87-89.

Harding, Sandra, The Science Question in Feminism. Ithaca: Cornell University Press, 1986.

Harrison, Beverly W., "The Role of Social Theory in Religious Social Ethics," in Making the Connections: Essays in Feminist Social Ethics, ed. Carol S. Robb. Boston: Beacon, 1985.

Jarl, Ann-Cathrin. In Justice: Women and Global Economics. Minneapolis: Fortress, 2003.

Johnson, Mark, Moral Imagination: Implications of Cognitive Science for Ethics. Chicago: University of Chicago Press, 1993.

Jones, Ken, The New Social Face of Buddhism. Somerville MA: Wisdom Publications, 2003.

Kahneman, Daniel and Amos Tversky, eds., Choices, Values, and Frames. New York and Melbourne: Cambridge University Press; New York: Russell Sage Foundation, 1994 [2000].

Keller, Evelyn Fox, Reflection on Gender and Science. New Haven, Conn: Yale University Press, 1985.

Kuiper, Edith and Jolande Sap, eds., Out of the Margin: Feminist Perspectives on Economic Theory. London and New York: Routledge, 1995.

Lakoff, George and Mark Johnson, Metaphors We Live By. Chicago: University of Chicago Press), 1980.

McFague, Sallie, Life Abundant: Rethinking Theology and Economy for a Planet in Peril. Minneapolis: Fortress, 2001.

Nelson, Julie A. Feminism, Objectivity and Economics. London: Routledge, 1996.

Nelson, Julie A., "Separative and Soluble Firms: Androcentric Bias and Business Ethics," in Feminist Economics Today: Beyond Economic Man, ed. Marianne A. Ferber and Julie A. Nelson. Chicago: University of Chicago Press, 2003a, 81-100.

Nelson, Julie A., "Confronting the Science/Value Split: Feminist Economics, Institutionalism, Pragmatism, and Process Thought," Cambridge Journal of Economics 27, no. 1 (2003b): 49-64.

Nelson, Julie A., "Breaking the Dynamic of Control: A Feminist Approach to Economic Ethics" Journal of Feminist Studies in Religion 19 (2003c): 27-45.

Nelson, Julie A. and Paula England, "Feminist Philosophies of Love and Work," Hypatia 17(2) (2002): 1-18.

Niebuhr, Reinhold, Moral Man and Immoral Society: A Study in Ethics and Politics. Louisville: Westminster John Knox Press, 1932 [2001]. On line at http://www.religion-online.org/. Introduction.

Novak, Michael Toward a Theology of the Corporation. Washington, D.C.: American Enterprise Institute, 1981. Excerpted in On Moral Business: Classical and Contemporary Resources for Ethics in Economic Life, ed. Max L. Stackhouse, 
Dennis P. McCann, and Shirley J. Roels, with Preston Williams. Grand Rapids: Eerdmans, 1995, 775-84.

Nussbaum, Martha, Poetic Justice: The Literary Imagination and Public Life (Boston, Mass.: Beacon Press, 1995.

Paine, Lynn Sharp, Value Shift: Merging Social and Financial Imperatives to Achieve Superior Performance. New York: McGraw-Hill, 2002.

Prigogine, Ilya (with Isabelle Stengers), The End of Certainty: Time, Chaos, and the New Laws of Nature. NY: The Free Press, 1997.

Robb, Carol S., Equal Value: An Ethical Approach to Economics and Sex. Boston: Beacon, 1995.

Schumacher, E. F., Small is Beautiful. New York: Harper \& Row, 1973.

Smith, Adam. 1759[1976]. The Theory of Moral Sentiments. Edited by D. D. Raphael and A. L. Macfie, Oxford: Clarendon Press.

Smith, Adam. The Wealth of Nations, 1776.

Solomon, Robert C. "Competition, Care, and Compassion: Toward a Nonchauvinist View of the Corporation," in Women's Studies and Business Ethics: Toward a New Conversation, ed. Andrea Larson and R. Edward Freeman. New York and Oxford: Oxford University Press, 1997, 144-173

Walzer, Michael, Spheres Of Justice : A Defense Of Pluralism And Equality. New York : Basic Books, 1983.

Wilson, Edward O., Consilience: The Unity of Knowledge. New York: Knopf, 1998. 
The Global Development And Environment Institute (GDAE) is a research institute at Tufts University dedicated to promoting a better understanding of how societies can pursue their economic goals in an environmentally and socially sustainable manner. GDAE pursues its mission through original research, policy work, publication projects, curriculum development, conferences, and other activities. The "GDAE Working Papers" series presents substantive work-in-progress by GDAE-affiliated researchers. We welcome your comments, either by e-mail directly to the author or to GDAE, Cabot Center, Fletcher School, Tufts University, Medford, MA 02155 USA; tel: 617-627-3530; fax: 617-627-2409; e-mail: gdae@tufts.edu; web: http://ase.tufts.edu/gdae.

\section{Papers in this Series:}

00-01 Still Dead After All These Years: Interpreting the Failure of General Equilibrium Theory (Frank Ackerman, November 1999)

00-02 Economics in Context: The Need for a New Textbook (Neva R. Goodwin, Oleg I. Ananyin, Frank Ackerman and Thomas E. Weisskopf, February 1997)

00-03 Trade Liberalization and Pollution Intensive Industries in Developing Countries: A Partial Equilibrium Approach (Kevin Gallagher and Frank Ackerman, January 2000)

00-04 Basic Principles of Sustainable Development (Jonathan M. Harris, June 2000)

00-05 Getting the Prices Wrong: The Limits of Market-Based Environmental Policy (Frank Ackerman and Kevin Gallagher, September 2000)

00-06 Telling Other Stories: Heterodox Critiques of Neoclassical Micro Principles Texts (Steve Cohn, August 2000)

00-07 Trade Liberalization and Industrial Pollution in Mexico: Lessons for the FTAA (Kevin Gallagher, October 2000) (Paper withdrawn- see www.ase.tufts.edu/gdael for details)

00-08 Waste in the Inner City: Asset or Assault? (Frank Ackerman and Sumreen Mirza, June 2000)

01-01 Civil Economy and Civilized Economics: Essentials for Sustainable Development (Neva Goodwin, January 2001)

01-02 Mixed Signals: Market Incentives, Recycling and the Price Spike of 1995. (Frank Ackerman and Kevin Gallagher, January 2001)

01-03 Community Control in a Global Economy: Lessons from Mexico's Economic Integration Process (Tim Wise and Eliza Waters, February 2001)

01-04 Agriculture in a Global Perspective (Jonathan M. Harris, March 2001)

01-05 Better Principles: New Approaches to Teaching Introductory Economics (Neva R. Goodwin and Jonathan M. Harris, March 2001)

01-06 The \$6.1 Million Question (Frank Ackerman and Lisa Heinzerling, April 2002)

01-07 Dirt is in the Eye of the Beholder: The World Bank Air Pollution Intensities for Mexico (Francisco Aguayo, Kevin P. Gallagher, and Ana Citlalic González, July 2001) 
01-08 Is NACEC a Model Trade and Environment Institution? Lessons from Mexican Industry (Kevin P. Gallagher, October 2001)

01-09 Macroeconomic Policy and Sustainability (Jonathan M. Harris, July 2001)

02-01 Economic Analysis in Environmental Reviews of Trade Agreements: Assessing the North American Experience. (Kevin Gallagher, Frank Ackerman, Luke Ney, April 2002)

03-01 Read My Lips: More New Tax Cuts-The Distributional Impacts of Repealing Dividend Taxation (Brian Roach, February 2003)

03-02 Macroeconomics for the $21^{\text {st }}$ Century (Neva R. Goodwin, February 2003)

03-03 Reconciling Growth and the Environment (Jonathan M. Harris and Neva R. Goodwin, March 2003)

03-04 Current Economic Conditions in Myanmar and Options for Sustainable Growth (David Dapice, May 2003)

03-05 Economic Reform, Energy, and Development: The Case of Mexican Manufacturing (Francisco Aguayo and Kevin P. Gallagher, July 2003)

03-06 Free Trade, Corn, and the Environment: Environmental Impacts of US - Mexico Corn Trade Under NAFTA (Frank Ackerman, Timothy A. Wise, Kevin P. Gallagher, Luke Ney, and Regina Flores, June 2003)

03-07 Five Kinds of Capital: Useful Concepts for Sustainable Development (Neva R. Goodwin, September 2003)

03-08 International Trade and Air Pollution: The Economic Costs of Air Emissions from Waterborne Commerce Vessels in the United States (Kevin P. Gallagher and Robin Taylor, September 2003)

03-09 Costs of Preventable Childhood Illness: The Price We Pay for Pollution (Rachel Massey and Frank Ackerman, September 2003)

03-10 Progressive and Regressive Taxation in the United States: Who's Really Paying (and Not Paying) their Fair Share? (Brian Roach, October 2003) 